\title{
Arts and Culture
}

\section{Iqbal $U^{*}$}

History Programme, Faculty of Social Sciences and Humanities, National University of Malaysia, Malaysia

*Corresponding author: Iqbal U, History Programme, Faculty of Social Sciences and Humanities, National University of Malaysia, UKM 43650, Bangi Selangor, Malaysia, Tel: 60389215555; E-mail: uqbah@siswa.ukm.edu.my

Received date: November 18, 2016; Accepted date: November 18, 2016; Published date: November 21, 2016

Copyright: $\odot 2016$ Iqbal U. This is an open-access article distributed under the terms of the Creative Commons Attribution License, which permits unrestricted use, distribution, and reproduction in any medium, provided the original author and source are credited.

Citation: Iqbal U (2016) Arts and Culture. Arts Social Sci J 7: e112. doi:10.4172/2151-6200.1000e112

\section{Editor Note}

The Arts and Social Sciences Journal is an international peer reviewed open access journal that publishes articles related to the latest developments in the field culture, literature, arts and other areas of social sciences. The current Volume 7, Issue 5 published 1 editorial article, 2 review articles, 7 research articles, 3 book reviews, 1 short commentary and 1 perspective article.

Iqbal [1] aims to review the pull and push factors involved and the characteristics of Japanese investment in Malaysia before and after independence. Bac, et al. [2] explore the Vietnamese postmodern literature. Hassen [3] touched on talk as an instrument of data collection for qualitative research. Alsaggar, et al. [4] state that arts in education are an expanding field of educational research and practice informed by investigations into learning through arts experiences. Abedini [5] aims to study history of Information Society, WSIS and United Kingdom measures regarding on Information Society and WSIS agendas. Iqbal [6] state that economics is a science that is very useful nowadays. Mahato [7] state togetherness the Nepali people experience during the enormous earthquake strikes should be continued and replicated in normal situation as well. Iqbal [8] introduces 30 major battles from the Ancient era to the present day. Each battle includes a concise account of the action, with a broader introductory context and an analysis of the aftermath. Momtaz [9] discusses to what extent the "West" has been successful in reshaping the Russian identity after the collapse of the Soviet Union. Makonnen [10] assess the impacts of youth outmigration on the socioeconomic and demographic behavior of migrant-sending households using survey data and in-depth interviews. Keshap [11] state that selfmanagement by professional and C.E.Os also contributes to management of big business houses. Glenn-Egil and Herner [12] investigate the importance of individual differences in short term memory capacity (STM) for learning from film (digitized video) and analogue text in a natural learning environment. Debasree [13] attempts to find a common space between Bollywood item numbers and hijra (transgender) dance performances exploring gender, sexuality and the idea that significance of body is especially problematic for these dancers. Goldshlak [14] state that in order to finish our way, and finally become the people, remained only, stop afraid and start thinking and understand. Madhusudhan [15] aims to give small review of festival as a culture in South India.

\section{References}

1. Iqbal U (2016) The historical development of Japanese investment in Malaysia (1910-2003). Arts Social Sci J 7: e108.

2. Bac LH, Thu Hang DT, Trung LV (2016) Chaos in "The General Retires" and "Without a King" by Nguyen Huy Thiep. Arts Social Sci J 7: 214.

3. Hassen R (2016) 'Talk' as a Research Data Collection Tool. Arts Social Sci J $7: 215$.

4. Alsaggar MA, Atoum MSA, Abdel-Karim SQ (2016) The future of art education. Arts Social Sci J 7: 216.

5. Abedini E (2016) The Global trends of WSIS: a case study of UK's plans and measures on information society. Arts Social Sci J 7: 217.

6. Iqbal U (2016) Book Review 'Introduction to Economics' (Malay Version). Arts Social Sci J 7: 218.

7. Mahato SK (2016) Togetherness in post-earthquake Nepalese society. Arts Social Sci J 7: 219.

8. Iqbal U (2016) Book Review 'Great Battles: decisive conflicts that have shaped history'. Arts Social Sci J 7: 220.

9. Momtaz T (2016) The significance of the 'West' in processes of post-soviet Russian identity formation (Societal and Cultural Perspectives). Arts Social Sci J 7: 221.

10. Makonnen KT (2016) The effects of rural youth outmigration on migrantsending households in Gojjam and Wolayta, Ethiopia. Arts Social Sci J 7: 222.

11. Keshap PK (2016) I am ok, you are not ok- a lesson from life. Arts Social Sci J 7:223.

12. Glenn-Egil T, Herner S (2016) Multimedia vs. Analogue text: learning outcome and the importance of short-term memory capacity. Arts Social Sci J 7: 224.

13. Debasree B (2016) Club and Courtyard: study on the intersection of Bollywood item numbers and 'Hijra' dance tradition. Arts Social Sci J 7: 225.

14. Goldshlak A (2016) Fear civilization. Arts Social Sci J 7: 226.

15. Madhusudhan L (2016) Floral festival: a culture of Telangana. Arts Social Sci J 7: 227. 